\title{
Merumuskan Masalah Penelitian dengan Metode MAIL
}

\author{
Ismail Suardi Wekke \\ Sekolah Tinggi Agama Islam Negeri (STAIN) Sorong, Indonesia \\ Email: iswekke@stainsorong.ac.id
}

Assalamu alaikum warahmatullahi wabarakatuh

Apa kabar semuanya? Semoga tetap sehat kan ya... di Kota Sorong itu sangat menyenangkan, suhu di atas 30 derajat celcius.

Saya disini kedinginan, Kota London sejak sore (21/1) mencapai 0 derajat.

Sebelum saya lanjutkan, Capaian Pembelajaran kita adalah "mahasiswa mampu merumuskan masalah penelitian".

Ketikan saya hari ini, hanya menegaskan 4 langkah dalam merumuskan masalah penelitian

Pertama, Mengamati Fenomena (M). Penelitian dimulai (dalam strategi kualitatif) dengan adanya fenomena.

Jangan sampai mengada-ada. Seperti "peran Lukman Hakim Saifuddin dalam transformasi penyuluh di Sorong Selatan"

Walau dalam kapasitas mentri agama tetapi beliau tidak bersentuhan langsung dengan urusan penyuluh di Teminabuan. Ini sebuah pernyataan yang mengada-ada untuk dijadikan sebuah topic penelitian.

Kedua, Analisis Topik Keilmuan (A).

Baca lagi ini:

https://www.researchgate.net/publication/325441207_Memulai_Penelitian_Dengan_Menganalisi s_Topik_Keilmuan.

Distingsi Kepemimpinan Transformatif, tidak memungkinkan didekati dengan monodisiplin, tetapi multidisiplin atau bahkan interdisiplin.

Maka, membaca pelbagai topik keilmuan akan membantu dalam hal mencermati masalah penelitian. Juga, dengan senantiasa bersedia melintasi tapal batal keilmuan sehingga terjadi frontiers of science.

\section{Ketiga, Identifikasi Masalah (I)}

Silahkan dibaca ini:

https://www.researchgate.net/publication/325256761_Memulai_Identifikasi_Masalah_Penelitian 
Masalah penelitian merupakan masalah yang perlu mendapatkan jawaban. Kalau sudah ada, jika tidak ada penambahan atau revisi, maka sebaiknya dihindari atau bahkan jangan diteliti sama sekali.

Ini akan terjadi pengulangan dan jutsru akan memunculkan kesia-siaan. Kecuali jika ada kebaruan, novelty dalam penelitian tersebut.

\section{Keempat, Kajian Literatur (L)}

Artikel berikut masih pada soal artikel. Sebagai bahan awal silahkan dibaca:

https://www.researchgate.net/publication/333731188_Penelusuran_Literatur_Dalam_Penulisan_ Artikel.

Memperkaya penelitian dengan literatur yang terpublikasi, paling tidak di bagian pendahuluan dan diskusi perlu literatur pendukung. Bahkan wajib.

Demikian empat langkah, saya buat akronim supaya mudah diingat MAIL.

Kunci dari matakuliah penelitian adalah membaca, mengamati, dan diskusi. Silahkan dibaca kembali:

https://www.researchgate.net/publication/335234334_Membaca_Mengamati_Mendiskusikan_da

$\underline{\text { n_Menulis_Tradisi_Akademik_di_Pasca_Sarjana }}$

Selamat membaca...

Waalaikumsalam Warahmatullahi Wabarakatuh 